\title{
Tumor Results Evaluator
}

National Cancer Institute

\section{Source}

National Cancer Institute. Tumor Results Evaluator. NCI Thesaurus. Code C117409.

A person who determines the significance of a tumor results assessment. 